\begin{tabular}{|c|c|c|c|c|c|c|}
\hline \multirow{4}{*}{ Impact Factor: } & ISRA (India) & $=3.117$ & SIS (USA) & $=0.912$ & ICV (Poland) & $=6.630$ \\
\hline & ISI (Dubai, UAE & $=0.829$ & РИНЦ (Russia) & $=0.156$ & PIF (India) & $=1.940$ \\
\hline & GIF (Australia) & $=0.564$ & ESJI (KZ) & $=8.716$ & IBI (India) & $=4.260$ \\
\hline & JIF & $=1.500$ & SJIF (Morocco) & $=5.667$ & OAJI (USA) & $=0.350$ \\
\hline
\end{tabular}

SOI: $1.1 /$ TAS $\quad$ DOI: $10.15863 / T A S$
International Scientific Journal
Theoretical \& Applied Science
p-ISSN: $2308-4944$ (print) $\quad$ e-ISSN: $2409-0085$ (online)
Year: $2019 \quad$ Issue: $04 \quad$ Volume: 72
Published: $10.04 .2019 \quad$ http://T-Science.org

SECTION 4. Computer science, computer engineering and automation.
QR - Issue

QR - Article
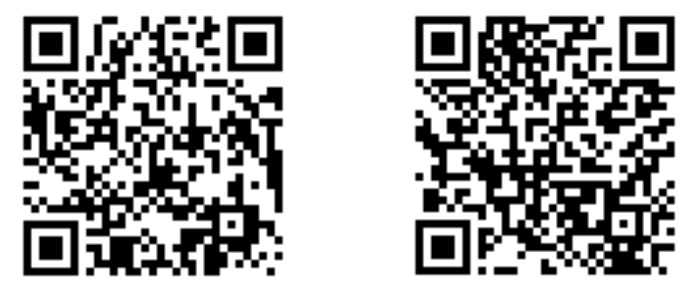

Gauhar Sarsenbaevna Borankulova TarSU them. M.H.Dulati Ph.D., i.o.dotsent

b.gau@mail.ru

Aigul Turyszhanovna Tungatarova TarSU them. M.H.Dulati Ph.D., i.o.dotsent at.tu@mail.ru

\title{
METHODS AND MEANS OF INFORMATION NETWORK PROTECTION
}

Abstract: The article discusses the choice of the optimal network protection option that would be convenient, did not create great difficulties in using the network and at the same time guaranteed a decent level of information privacy protection.

Key words: Information security, network, information, information security system.

Language: English

Citation: Borankulova, G. S., \& Tungatarova, A. T. (2019). Methods and means of information network protection. ISJ Theoretical \& Applied Science, 04 (72), 75-78.

Soi: http://s-o-i.org/1.1/TAS-04-72-13 Doi: crossef https://dx.doi.org/10.15863/TAS.2019.04.72.13

\section{Introduction}

Initially, the development of the problem of protecting the privacy of the network arose due to the fact that the owner of the information for their own reasons did not want to share it. And with the development of NTP and NTR, there was an increase in the scale of human activity, as a result of which a new characteristic distinction from simple knowledge - "price" - appeared. A person who possesses information can produce all sorts of manipulations with it, but the final result will still be getting a certain benefit (material, military, political, etc.), it all depends on what goals the owner of a limited resource has.

Information technologies are rapidly developing in the 21st century, more and more taking root in our everyday life, and life without them is already unimaginable. Information technologies have penetrated into all spheres of activity: education, economics, politics, manufacturing, so-called service services have appeared, which markedly facilitated the exchange of information between different business units. Information at the present stage is not just an expensive, exclusive resource, but also a stream of certain information about the strategic nature of a particular entity, the disclosure of which causes irreparable damage and may lead to bankruptcy. For example, losses due to the recovery of information, losses due to interruptions of production, losses due to the loss of most significant customers.

\section{Materials and Methods}

Information technology, being a military development of the NATO, significantly simplified such processes as production, distribution, exchange and consumption, which contributed to accelerating the product life cycle and maximizing profits. Actually, such a "tidbit" as information about the data of a successful company cannot remain unnoticed for a long time by attackers who carry out various types of attacks in order to gain access to confidential information. In this connection, the problem of information security becomes more acute. After all, it was not without reason that Mayer Rothschild said the phrase, which became winged: "Who owns the information, he owns the world."

Using the latest methods and means of information network protection, it is impossible to achieve absolutely perfect network security and, moreover, network security increase leads to inconveniences in its use, restrictions and difficulties 


\begin{tabular}{|c|c|c|c|c|c|c|}
\hline \multirow{4}{*}{ Impact Factor: } & ISRA (India) & $=3.117$ & SIS (USA) & $=0.912$ & ICV (Poland) & $=6.630$ \\
\hline & ISI (Dubai, UAE & $=0.829$ & РИНЦ (Russia) & $=0.156$ & PIF (India) & $=1.940$ \\
\hline & GIF (Australia) & $=0.564$ & ESJI (KZ) & $=8.716$ & IBI (India) & $=4.260$ \\
\hline & JIF & $=1.500$ & SJIF (Morocco & $=5.667$ & OAJI (USA) & $=0.350$ \\
\hline
\end{tabular}

for users. Moreover, it is necessary to choose the best option to protect the network, which would be convenient, did not create great difficulties in using the network and at the same time guaranteed a decent level of information privacy protection.

The relevance of the topic of this work is to properly ensure the security of information in the network - this is one of the fundamental components of its optimally stable operation. Maintaining of which requires the performance of controlling functions, timely modernization of outdated anti-virus databases and the use of innovative methods and means of such information protection. Therefore, as long as there are threats to the security of information in networks, questions of methods and means of protection will remain relevant.

The Information Security System (ISS) is a multifaceted, multilateral set of tools, methods and measures to protect information. When considering the structure of an ISS, a traditional approach is possible that would single out the subsystems providing it.

In the information security system, the target functions have specific types of their own software and other software, with which the system will perform protective functions. Next, we consider in more detail the types of such software. It is impossible to talk about security guarantees without a legal framework, which is a set of regulatory and by-laws, regulations, job descriptions, manuals, the requirements of which are mandatory.

Organizational support is of paramount importance, as it usually implies the implementation of information security with the help of specialized structural units (for example, security, security service, etc.)

Information support contains the parameters, information, indicators and basic data for solving problems that ensure the functioning of the ISS. Hardware is a complex tooling system with technical means for the functioning of an effective security system.

Of course, the ISS has the necessary software. This refers to various accounting, statistical and information programs that can provide an objective assessment of the presence of dangerous channels of leakage and identify ways of unauthorized access to confidential data.

In addition, the ISS also has its foundational basis on mathematical software, which contains mathematical methods used in calculating the risk assessment of technical means that intruders have to calculate the norms of sufficient protection.

And finally, the regulatory and methodological support has the norms and regulations of the activities of the services, bodies and means, which are various methods of ensuring information security. It should be noted that of all protective measures in the present, the main role is played by organizational measures. So, the question arises about the organization of security services.

Let us turn to specific methods and means of ensuring the security of information.

The fundamental and paramount method of protection is the obstacle method, which is based on physically blocking the attacker's path to information.

The second, more important method is the access control method - a method of protecting the confidentiality of information by regulating the use of all IT and IP resources.

You can also secure data transmission over communication channels using encryption mechanisms. The encryption mechanism is a cryptographic closure of information. It should be emphasized the special reliability of this method. But there is a weak spot in cryptographic systems - this is the problem of key distribution.

The most important protection function is the function of countering attacks of virus programs, which has in its arsenal a whole range of various measures and the use of anti-virus programs and, if necessary, the restoration of IP after a virus attack.

Software tools are of no small importance and are a complex of special programs and software systems designed to protect the confidentiality of information in the IP.

In addition to the above, there are still organizational, legislative and moral-ethical remedies. Organizational means carry out production activities in IP in such a way that information leakage is impossible and all processes in IP are under the control of management.

Legislative remedies are described by the laws of the country that regulate the rules for using, processing and transmitting information of limited access and establish penalties for violation of these rules.

There are moral and ethical remedies that have traditionally been established earlier but can also be developed intentionally. A typical example of such regulations is the Code of Professional Conduct of the Members of the US Computer Users Association. tools:

We list the standard operating system security

1. This is primarily a security event $\log$.

The security event $\log$ for the enterprise is mandatory, as it allows you to monitor the attempt to hack the network and track the source.

2. A second, equally important tool is the Encrypting File System (EFS) encrypted file system.

It makes it possible to significantly strengthen the protection of information by encrypting files and folders on NTFS volumes. The principle of encrypting 


\begin{tabular}{|c|c|c|c|c|c|c|}
\hline \multirow{4}{*}{ Impact Factor: } & ISRA (India) & $=3.117$ & SIS (USA) & $=0.912$ & ICV (Poland) & $=6.630$ \\
\hline & ISI (Dubai, UAE & $=0.829$ & РИНЦ (Russia) & $=0.156$ & PIF (India) & $=1.940$ \\
\hline & GIF (Australia) & $=0.564$ & ESJI (KZ) & $=8.716$ & IBI (India) & $=4.260$ \\
\hline & JIF & $=1.500$ & SJIF (Morocco & $=5.667$ & OAJI (USA) & $=0.350$ \\
\hline
\end{tabular}

an EFS file system is that folders and files are encrypted using pair keys.

Therefore, to decrypt data, the user who wants to access files and folders must have a special key.

3. Registration cards of users.

At the enterprise, each employee has a special registration card for using the resources of the local network where the user information is located - the name, password, and restrictions on the use of the network.

4. Control over network activities

5. Determination of user rights, which include logging into the local computer, setting the time, copying and restoring files from the server and performing other tasks.

6. Control over sessions at workplaces.

If the username and password are similar to those in the account card, the server notifies the workstation that the session has started. The server also loads other information when starting a user session, such as user settings, its own directory, and environment variables.

7. The policy of registration cards and passwords.

The enterprise has all aspects of the password policy: a password length of 8 characters, the age of the password and the originality of the password, which guarantees the protection of the user from changing his password.

At the present time, none of the directions of the branches of economic activity cannot do without the means and methods of protecting the confidentiality of, especially important resources.

The modern market for innovative technologies has a huge range of hardware and software designed to ensure data integrity.

Therefore, it is very important to choose such a rational ratio as the optimal data privacy protection and reasonable price.

To date, it is impossible to imagine what responsibility the choice of antivirus is reliable for any user, who could easily guarantee the stable operation of a personal computer and immunity to its files. According to the rating of the most popular free programs you can select the following types:

1. Avast Free Antivirus - an excellent proven free antivirus, which has earned recognition of millions of users thanks to its reliable protection against Trojans and viruses.

2. 360 Total Security - a powerful set of tools to maintain the normal functioning of the operating system.

3. Panda Antivirus Pro - a characteristic feature is the protection of the user's computer from the most well-known types of virtual threats.
4. ESET NOD32 Smart Security - a great comprehensive solution to protect your computer from viruses, trojans, adware and from spam.

5. Avira Free Antivirus - the most common antivirus, which is capable of quite effective protection against viruses. Not many can boast such an advantage over rivals like going to cloud technology, which is able to protect a computer from the latest threats.

\section{Conclusion}

In the course of researching the topic of the article: "Methods and means of protecting information in networks", it was revealed that anti-virus protection is a fundamental, dominant basis for maintaining the integrity of an information system, especially as those wishing to encroach on the confidentiality of information circulating in networks increases exponentially.

Thus, the most rational decision, according to the author, to ensure security in the IP, the system administrator needs to take into account not only the basic principles of information security but also to monitor constantly improving methods and methods of protection. A specific information security policy should be created, taking into account such parameters as the characteristics of the organization, the nature of its activities and budget. In the age of progress and rapid development of innovations, constant quality monitoring is required to identify new potential threats, and, in accordance with this, timely updating of software and hardware protection systems.

Information is the most valuable and expensive resource, serving as an exclusive product in the world, for which there has always been and will be in demand. For this reason, the attackers, using all sorts of sophisticated methods, have tried and will try to seize this limited resource to meet their own needs.

At the moment, IT technology is the most profitable line of business, requiring minimal investment and guaranteeing maximum profit in the case of creating unique, previously non-existent innovations. According to the latest media reports, this activity is ranked first in the world. But, unfortunately, venture companies pursue, as is known, not always noble goals. Therefore, the development of information technologies encourages the unification of efforts by various IT specialists around the world to improve methods and means that could fully and qualitatively assess the threats to the security of the information sphere and react to them in a timely manner. 


\begin{tabular}{|c|c|c|c|c|c|c|}
\hline \multirow{4}{*}{ Impact Factor: } & ISRA (India) & $=3.117$ & SIS (USA) & $=0.912$ & ICV (Poland) & $=6.630$ \\
\hline & ISI (Dubai, UAE & $=0.829$ & РИНЦ (Russia & $=\mathbf{0 . 1 5 6}$ & PIF (India) & $=1.940$ \\
\hline & GIF (Australia) & $=0.564$ & ESJI (KZ) & $=8.716$ & IBI (India) & $=4.260$ \\
\hline & JIF & $=1.500$ & SJIF (Morocco & $=5.667$ & OAJI (USA) & $=0.350$ \\
\hline
\end{tabular}

\section{References:}

1. Kupriyanov, G. I. (2009). Internet Information Resources. (p.132). Moscow: EDEL.

2. Levin, V. K. (2009). Information protection in information and computing systems and networks. Programming, N3, p. 67.

3. Pravikov, D. I. (2009). Key diskettes. Development of elements of systems to protect against unauthorized copying. (p.67). Moscow: Radio and communication.

4. Severin, V. A. (2010). Comprehensive information security in the enterprise. Grif UMO MO RF. (p.77). Moscow: Gorodets.

5. Severin, V. A. (2010). Comprehensive information security in the enterprise. Grif UMO MO RF. (p.108). Moscow: Gorodets.

6. Hofman, L. (2009). Modern methods of information security. (p.45). SPb.: Peter.
7. Schneier, B. (2009). Applied Cryptography. Protocols, algorithms, source texts in the $S$. language. (p.173). Moscow: TRIUMPH Publishing House.

8. Fufayev, D. E. (2010). Development and operation of automated information systems. Moscow: Academy.

9. Stankevich, K. S. (2018). Methods and means of information protection in networks. Scientific community of students of the XXI century. TECHNICAL SCIENCES: Sat. Art. on the mat. LI Intern. stud scientific-practical conf. Number 3 (50). Retrieved Dec. 03, 2019, from https://sibac.info/archive/technic/3(50).pdf

10. Melnikov, V. P. (2011). Information Security and Information Security. Moscow: Academy. 